\title{
Eszterházy Károly püspök és székhelye, Eger városa
}

\section{Eger a török kiűzését követő században}

Eltekintve a Rákóczi-szabadságharc éveitől, a 18. század Egerben a békés fejlődés időszaka volt, amit gazdasági konjunktúra is kísért. Igaz ez annak ellenére, hogy az egri polgárság viszonya a püspökkel és a káptalannal mint földesuraival gyakorlatilag az egész 18. század folyamán kisebb-nagyobb konfliktusokkal volt terhelt. ${ }^{1}$

Így volt ez Eszterházy Károly esetében is, aki a káptalannal együtt földesúri jogokat gyakorolt a város lakossága felett. A város két vármegye - Heves és Borsod - területén helyezkedett el, a hevesi részen - a pataktól nyugatra - a püspök, a borsodi részen pedig - a pataktól keletre - a káptalan volt a földesúr. Teljes jogú polgárok csak a fallal körülvett belváros lakói voltak - ők egy összegben, egyetemlegesen fizették a földesuraknak járó szolgáltatásokat - a külvárosok lakói azonban tényleges jobbágyi sorban éltek, és fejenként adóztak földesuraiknak egészen a feudális korszak végéig. ${ }^{2}$

A város polgárai az 1687-ben bekövetkezett felszabadulás óta egészen a 18. század végéig több kísérletet tettek arra, hogy a település a szabad királyi városok sorába emelkedjen. Elsőként Fenessy György püspök idején, még a 17. század utolsó éveiben, közvetlenül a török kiüzése után. Eger mint új szerzeményi birtok szabad királyi városi rangra emelkedhetett volna (erről I. Lipót 1688-ban egy resolutiót is kiadott). Amikor azonban az egri püspökség és káptalan bizonyítani tudták régi birtokjogukat, és kifizették a fegyverváltságot, a rangemelés érvényét vesztette, és a város az úgynevezett püspöki mezövárosok sorába került vissza. 1694-ben Lipót visszavonta a resolutiót, a város pedig kiegyezett földesuraival. Ez azt jelentette, hogy a lakosság belenyugodott a rangemelés elmaradásába, a püspök és a káptalan pedig bizonyos kiváltságokkal kárpótolta ezért őket: többek között az önrendelkezés, a bíróválasztás (a püspök által jelölt három személy közül) és az egész belvárosra egy összegben megállapított adózás lehetőségével, aminek összegét ráadásul hosszú évekre előre állapították meg. A püspök és a káptalan bizonyos jogokat

1 Bél Mátyás: Heves megye ismertetése, 1730-1735. Fordította és magyarázatokkal ellátta: Soós Imre. Eger 1968. 65.

2 Bél M.: Heves megye i. m. 65. 
(vásár-, kocsma-, mészárszéktartás stb.) megosztott a lakossággal. Ez az egyezmény a Fenessy-féle transactio néven vonult be Eger történetébe, és egészen 1854-ig a település működésének jogforrása volt. Aláirására 1695. január 4-én, Kassán került sor ${ }^{3}$ (ennek ellenére 1848-ig a város több alkalommal próbálta a szabad királyi rangot megszerezni). A transactio kedvezőnek bizonyult a városlakók részére, mert Mária Terézia 1767-ben meghozott úrbéri rendelete után 1771-ben Eszterházy püspök felajánlása nyomán a lakosság az urbárium helyett a sokkal előnyösebb transactio mellett döntött. Ez a döntés csak rövid távon bizonyult hasznosnak, mert néhány évtized múlva az 1848-as törvények, melyek a jobbágyságot (állami kárpótlás mellett) az általa használt földek birtokába juttatták, nem vonatkoztak a nem úrbéri jellegü földekre.

Később II. József és Eszterházy közismerten rossz viszonyát kihasználva a város lakossága 18 pontból álló memorandumot nyújtott be az uralkodónak felszabadítási kérelmével, ${ }^{4}$ aki 1789 decemberében tájékoztatta Eger lakosságát és a püspököt, hogy a települést a szabad királyi városok sorába kívánja emelni. Két hónappal később bekövetkezett halála akadályozta meg ebben. ${ }^{5}$

Számos ellentét forrása volt az is, hogy a püspökök által foglalkozatott iparosok és művészek nem voltak hajlandók a városnak megfizetni a letelepedés lehetőségéért járó összeget, az úgynevezett purger taxát (a „purger” a Bürger német szó módosulása). Így nemcsak a város magisztrátusa esett el jelentős bevételtől, hanem a püspök alkalmazottai konkurenciát is jelentettek az itt élő céhes iparosoknak. Megjegyzendő, hogy Eszterházy tanult elődje, Barkóczy Ferenc esetéből - aki ellen 1756-ban fellázadtak a helybeli kézművesek -, ezért ő már előszeretettel foglalkoztatott helybeli iparosokat is, sőt az általa ideinvitált idegenek is többnyire „egrivé” váltak. Letelepedtek, házat vettek, egri leányt vagy özvegyet vettek feleségül, ezáltal polgárjogot nyertek. ${ }^{6}$ De azért az ő emberei közül is sokan szembeszegültek a céhekkel, illetve a magisztrátussal.

Eszterházy Károly a török kiűzését követő korszak egri püspökei sorában a legmarkánsabb személyiség volt, aki közel 40 éves itt-tartózkodása során többet tett székvárosáért, mint bárki előtte vagy utána. Nagyvonalúsága és áldozatkészsége is minden idők legönzetlenebb egri püspökévé tették. „A kormányzásban szóval és

3 Heves Megyei Levéltár (a továbbiakban HML) Az Egri Főkáptalan Magánlevéltára XII.-2/d/44. 81. A Fenessy-féle transactio.

4 HML Az egri Főkáptalan Magánlevéltára, nagypréposti iratok II. A-II. -37, XII-2/c/2 Az egriek sérelmei, melyeket II. József elé tártak. Elsősorban a szőlőföldek allodizálása ellen tiltakoztak, de amiatt is, hogy a transactio által biztosított haszonvételeket a földesurak kisajátították, egyúttal a földesúri terheket megemelték.

5 Szederkényi Nándor: Heves vármegye története IV. Eger 1891. 144-246.

6 Löffler Erzsébet: Eger város jogi helyzete a török kiűzésétől 1854-ig. In: Agria XVIII. Az Egri Múzeum Évkönyve. Szerk. Bodó Sándor. Eger 1981. 87. 
tettel olyannyira bizonyította kegyességét, szeretetét és bölcsességét, hogy mindazok, akik ismerik, a magyarországi papság tükrének tartják.” Egri püspökké való kinevezése előtt a bécsi nuncius által végzett processzus egyik tanúja így nyilatkozott Eszterházy püspökről: ${ }^{7}$

Eszterházy puritán ember volt, sohasem értett egyet a céltalan fényűzéssel, építkezéseit - amelyeket viszont művészi igénnyel végeztetett - mindig magasabb célok és eszmék szolgálatába állította. Egyszerü életvitele az élet minden területén megnyilvánult; rendkívül fegyelmezett életmódot folytatott, korán kelt, sokat dolgozott, és egyházkormányzati tevékenysége mellett mindig végzett lelkipásztori munkát is. ${ }^{8}$

A püspök hatalmas bevételeinek csak töredékét használta föl személyes célokra, azonban semmilyen nehézségtől nem riadt vissza akkor, amikor az általa elképzelt nagyvonalú tervek megvalósításáról volt szó. Nagyszabású építkezéseihez magánvagyonát is felhasználta, tehát nem kizárólag a reá bízott közösség, az egyházmegye jövedelméből gazdálkodott. Eszterházy igényes, fizetőképes megrendelő volt, aki a pénzéért minőséget, pontosságot és megbízhatóságot várt el, ha valaki ezeknek a követelményeknek nem tudott eleget tenni, mennie kellett.

$\mathrm{Az}$ a legenda kapcsolódik a nevéhez, mely szerint a Líceum építésével kapcsolatos számlákat megsemmisítette. Ez nem igaz, de felvetődik a kérdés, hogy a hatalmas építkezéshez szükséges pénzt honnan teremtette elő. Eszterházy bevételeiről tájékozódhatunk Sugár István egri püspökökről szóló könyvéből, ennek alapján kirajzolódik előttünk egy nagyvonalú, rendkívül gazdag mecénás alakja. Püspöki jövedelmei három részből tevődtek össze, egyrészt a püspökség saját birtokainak jövedelméből, másrészt a földesúri járandóságokból, végül pedig az egyházmegyei dézsmabevételekből. Ezeket azonban még kiegészítették a püspök személyes vagyonából származó bevételek is, a pápai, a devecseri és az ugodi családi birtokok jövedelmei. Gazdálkodásának illusztrálására az említett szerző az alábbi példával szolgál: 1771 és 1797 között évi átlag 190000 forint jövedelméből évente nagyjából 16000 forintot vett föl „úgymond” saját céljaira, de ezekből a saját célokra felvett összegekből vásárolta meg például a Líceum könyvtárába szánt könyveket is. ${ }^{9}$

Eszterházy fö művével, a Liceum felépítésével nemcsak egy reprezentatív épülettel gazdagította a városképet, hanem át is tette a hangsúlyt az Universitas monumentális épületére. Ez lett a város legnagyobb, legtekintélyesebb, emiatt emblematikus épülete. Ezt a „funkciót” korábban a püspöki palota töltötte be. Ebben az időszakban a városi

7 Tusor Péter: Eszterházy Károly kánoni kivizsgálási jegyzőkönyvei a Vatikáni Levéltárban. In: Eszterházy Károly emlékkönyv. Szerk. Kovács Béla. Eger 1999. 35.

8 Nováky József. Halotti dicséret, mellyet Nagy Méltóságú és Fő Tisztelendő Galántai s ' Fraknói Gróf Eszterházy Károly, egri püspöknek... mondott tisztelendő Nováky József kömlői plébános... Eger 1799. 15-21.

9 Sugár István: Az egri püspökök története. Bp. 1984. 427-428. 
magisztrátus nem rendelkezett sem elegendő hatáskörrel, sem a szükséges anyagiakkal ahhoz, hogy bármely városi ingatlan - például a városháza - közvetlen környezetébe tudta volna szervezni a centrumot. Ez csak a polgári korszakban következett be. A Líceum hatalmas és elegáns tömege ugyanakkor még feltűnőbbé tette a szemközti katedrális jelentéktelenségét, amely a Líceumhoz képest még úgy is eltörpült, hogy a vele szemközti magaslaton állt. Ezért is tartotta fontosnak Eszterházy az új katedrális megépítését, attól függetlenül, hogy természetesen a püspökség rangjához méltó, nagyobb méretű székesegyházra egyébként is szükség lett volna. Mint tudjuk, ezt csak Pyrker érsek valósította meg a következő század közepe táján. A sors különös fintora, hogy Eszterházynak sem Vácott, sem Egerben nem sikerült új székesegyházat építtetni, noha Vácott - Egerrel ellentétben - épp ez volt az első önmaga számára kitűzött cél, az ott eltöltött idő azonban kevésnek bizonyult a megvalósításhoz. Utóda, Migazzi Kristóf pedig túl költségesnek tartotta a Pilgram által készített terveket, ezért új tervezőt bízott meg. Egerben viszont életműve végére hagyta a katedrális építését, ezzel akarta megkoronázni itteni működését, ám itt „kifutott az időől”.

Székvárosában nemcsak olyan épületeket hozott létre vagy támogatott, melyek a püspöki reprezentáció nélkülözhetetlen helyszínei, illetve kellékei voltak, és bárhol Európában méltón képviselhették volna egy egyházmegye központját, hanem a kor szükségleteinek megfelelően egy modern intézményhálózat felépítésén is fáradozott. A püspöki iskoláknak egy négykarú egyetembe való integrálása (illetve annak terve), az egyetem épületének felállítása és berendezése pedig arra utaló jel volt, hogy székvárosát a nagyvonalú püspök szellemi központtá, a tudomány fellegvárává is kívánta tenni. Ez utóbbi törekvésében nagy szerepet játszottak a római benyomások, a „kis Róma” kifejezés nemcsak városrendezési és építészeti tartalommal bírt, hanem itthoni kamatoztatása is volt mindannak a szellemi muníciónak, amelyet a Rómában tanult fópapok hoztak magukkal.

\section{„A magyarországi papság tükre”}

A püspök családi körülményei, tanulmányai, római tartózkodása meghatározó szerepet játszottak személyiségének alakulásában, amelynek legfőbb vonásai a mély és elkötelezett hit, a reábizottakért érzett felelösségtudat és a rendkivüli müveltség voltak.

Olyan aulikus katolikus arisztokrata családba született, amely predesztinálta a későbbi sikeres életpályára, és ahol a szűkebb vagy tágabb família tagjai szinte minden számottevő világi vagy egyházi pozíciót betöltöttek. Eszterházy Károly édesapja Esterházy Ferenc, édesanyja pedig Pálffy Szidónia, gróf Pálffy Jánosnak, 
a szatmári békekötés császári megbízottjának a leánya volt. Édesanyja hét fiú- és hat leánygyermeknek adott életet, ezek közül három fiú hamar meghalt. Károly a nyolcadik gyermek volt, 1725. május 4-én Pozsonyban született. Családtagjai közül nagy hatást gyakorolt rá fivére, Esterházy Ferenc, a későbbi kancellár, és apai nagybátyja, Esterházy Imre, veszprémi püspök, későbbi esztergomi érsek. Esterházy érsek is nagy építtető volt, akinek Pozsony számtalan építészeti értéke köszönheti létét. Eszterházy Károly ilyen irányú indíttatása egészen idáig vezethető vissza. ${ }^{10}$

Iskoláit Pozsonyban, a jezsuiták gimnáziumában kezdte. Itt a latin nyelven kívül klasszikus irodalmat, poétikát, retorikát, történelmet tanult. ${ }^{11} \mathrm{~A}$ jezsuiták iskoláiban nagy hangsúlyt helyeztek a nyilvános disputákra és a színpadi előadásokra is, melyek felkészítették a tanulókat a későbbi nyilvános szereplésekre. A lelki életre való nevelés a Mária Kongregációban történt. Kitűnő tanulmányi eredményei, tehetsége és szorgalma révén előbb a jezsuiták nagyszombati kollégiumába került, ahol filozófiát és teológiát tanult az 1745/46-os tanévben. Innen került a római Collegium Germanicum et Hungaricumba 20 éves korában. Ez az intézmény Eszterházy idejében a Szent Apollináris palotában - Palazzo Sant’ Apollinare - müködött. Nagyszombati előtanulmányainak köszönhetően egyből a theologia speculatíva második évfolyamára vették föl. A kollégium matrikulái mindig a legnagyobb elismeréssel szóltak tehetségéről, hamarosan az újoncok magistere lett. ${ }^{12}$

A Collegium Germanicum et Hungaricum diákjai a Collegium Romanumban, a jezsuiták központi egyetemén tanultak, ahol Európa vezető teológusainak előadásait hallgatták. Eszterházy is itt tanult, tanárai között volt Pietro Lazzari, aki a Collegium Romanum könyvtárosa és professzora volt. Bizonyára nem múlt el nyomtalanul az ő hatása sem a későbbi püspökre, elég, ha csak könyvgyüjtő szenvedélyére és ennek nyomán létrehozott könyvtárára gondolunk. ${ }^{13}$

A Rómában töltött három évvel kapcsolatban említést érdemel az is, hogy saját szemével láthatott kitűnő műalkotásokat. Óriási hatást gyakorolt rá például Francesco Borromini (1599-1667), a svájci származású Itáliában tevékenykedő építőművész által hátrahagyott életmü, aki a barokk építészet meghatározó személyisége volt. ${ }^{14} \mathrm{~A}$ fiatal papnövendéket különösen a Collegium Germanicum et Hungaricum közelében

10 Kádár László: Eszterházy Károly racionalizmusa. In: Kétszáz éves az Egri Főegyházmegyei Könyvtár. Szerk. Antalóczi Lajos. Eger 1993. 69-70.

11 Bitskey István: Római hatások a barokk kori magyarországi föpapi könyvgyüjtésben. In: Kétszáz éves az Egri Főegyházmegyei Könyvtár. Szerk. Antalóczi Lajos. Eger 1993. 69-71.

12 Bitskey I.: Római hatások i. m. 8.

13 Bitskey István: „Püspökünk, példánk és tükörünk volt” Eszterházy Károly életpályája és egyénisége. In: Eszterházy Károly emlékkönyv. Szerk. Kovács Béla. Eger 1999. 9.

14 Polónyiné Kiss Adrien: Főpapi könyvtárak múltja és jelene. Adatok az Egri Főegyházmegyei Könyvtár történetéhez. Szakdolgozat. Eszterházy Károly Főiskola, Médiainformatikai Tanszék. Eger 2007. 15. 
lévő Sant' Agnese in Agone-templom, Borromini talán legnagyobb alkotása nyügözte le. Több kortárs művésszel személyesen is megismerkedhetett. ${ }^{15}$

A Collegium tanárai, sőt többnyire diákjai is tagjai voltak az Árkádia tudós társaságnak. Körükben ismerkedett meg a janzenizmussal, mely a katolikus egyházon belüli, a kálvinizmushoz közel álló reformmozgalom volt, elsősorban Franciaországban terjedt el a 17-18. században. Nevét a leuweni Jansenius püspökről (1585-1638) kapta. ${ }^{16}$

Biztos nagy hatást gyakoroltak rá Lodovico Antonio Muratori (1672-1750) olasz tudós történetíró eszméi is, aki a reformkatolicizmus megalapítója volt. ${ }^{17}$ Muratori fontosnak tartotta a túlburjánzó barokk pompa háttérbe szorítását, és az evangélium eredeti szelleméhez kívánt visszatérni, mely szerint a fóparancs a szeretet. Az volt a véleménye, hogy a szenteknek nincs szükségük a mi hódolatunkra, de a szegényeknek szüksége van arra, hogy segítsünk rajtuk. A pompa, a luxus kerülése és az elesettekhez való odahajlás végigkísérte Eszterházy életét is. Muratorit sokan eretneknek tartották, ám XIV. Benedek pápa szerint műveinek egyetlen gondolata sem volt ellentétes a katolikus egyház tanításával. Ennek ellenére a magyar egyháztörténészek sokszor őt hibáztatták II. József egyházpolitikájaért, sőt nevét még a szabadkőművességgel is kapcsolatba hozták (muratore olaszul: kőműves). Napjainkban Ferenc pápa próbálkozik hasonló szellemben gyakorolni „hatalmát”.

Rómában szerzett kapcsolatait egész további élete során jól kamatoztatta, így mindig voltak friss információi nemcsak az Örök Város, hanem Európa több jelentős egyházi központjának eseményeit illetően. ${ }^{18}$

Eszterházy egyébként a fenti tapasztalataiból kiindulva elődeinél jóval több papot küldött római tanulmányokra, és az egyetem létesítésével biztosítani akarta azt is, hogy hazai körülmények között is szert lehessen tenni magas szintű műveltségre, képzettségre.

Személyisége összetett volt, egyrészt példaképei (Borromeo Szent Károly, Szalézi Szent Ferenc és XIV. Benedek pápa) ${ }^{19}$ nyomdokain kivánt haladni, a katolikus megújulás tántoríthatatlan híveként a Trienti zsinat határozatainak következetes végrehajtójává vált. Mély vallásossága arra ösztönözte, hogy tartózkodjon minden szélsőségtől, mindent megtegyen a katolikus megújulásért és a szakadárok

15 Nováky J.: Halotti dicséret i. m. 6.

16 Bitskey I.: „Püspökünk, példánk” i. m. 9.

17 Szelestei Nagy László: Eszterházy Károly, a püspök. In: A helyi érték. Kulturális örökség tanulmányok. In Agriam adveni. Szerk. Monok István. Eger 2013. 35-37.

18 Tóth Tamás: A Collegium Germaicum et Hungaricum szerepe Eszterházy Károly életében. In: A helyi érték. Kulturális örökség tanulmányok. In Agriam adveni. Szerk. Monok István. Eger 2013. 69.

19 Bitskey I.: „Püspökünk, példánk” i. m. 17. 
visszatereléséért a katolikus egyházba. Rendkívüli lelkipásztori képességeinek köszönhetően Borromeo Szent Károly (1538-1584) példájára nemcsak jó püspök, de jó pap is volt, aki naponta misézett, kánoni vizitációi során minden templomot és plébániát meglátogatott, és híveinek személyesen szolgáltatta ki a szentségeket. Borromeo Szent Károly nemcsak védőszentje volt Eszterházynak, hanem minden Rómában tanult fôpap példaképe, aki a Trienti Zsinat határozatainak első végrehajtója volt. Különös érdeme továbbá, hogy a milánói pestisjárvány idején nagy áldozatkészségről tett tanúságot, amikor nem menekült el, hanem megszervezte a betegek gyógyítását. ${ }^{20} \mathrm{~A}$ szentéletű milánói püspök szemináriumokat, kórházakat, templomokat fôpapi rezidenciákat építtetett, Eszterházy nemcsak e területeken követte a példáját, állítólag az ő napirendje szerint is élt. ${ }^{21}$

Példaképei közül legkevésbé Szalézi Szent Ferencre volt képes hasonlítani, noha lélek-és egyházépítő munkáját igyekezett a tőle tanult szeretetteljes türelemmel végezni. Szalézi Szent Ferenc (1567-1622) nem véletlenül szerepelt az ideálok sorában. A szentéletủ genfi püspök a katolikus hit védelmében úgy szerzett elévülhetetlen érdemeket, hogy hihetetlen szelídséggel végezte azt. Az volt az álláspontja, hogy „egy csepp mézzel többet lehet fogni, mint egy vödör ecettel”. Páli Szent Vince mondta róla, hogy „milyen jó lehet az Isten, ha már a genfi püspök is ilyen jó”. ${ }^{22}$ Az ő példája azért volt fontos Eszterházynak, mert tisztában volt saját gyengeségeivel, sok konfliktusa volt nemcsak a protestánsokkal, hanem egyházmegyéjében a görögkatolikusokkal, székvárosában az ortodox hitűekkel is, és tisztában volt azzal, hogy vallási türelmetlensége nem egyeztethetö össze a szeretet parancsával. Ezzel kapcsolatban elég, ha említést teszünk az egri szerbek és görögök - együttesen rácok - templomépítésével kapcsolatos gáncsoskodásairól. Ennek a konfliktusnak II. József 1784-es egri látogatása vetett véget, aki a Helytartótanácson keresztül még abban az évben engedélyezte a rácoknak új templomuk fölépítését.

Építkezései során XIV. Benedek pápa (1675-1758) volt a követett példakép. A pápa maga is tudós volt, és bőkezűen támogatta és fejlesztette a Vatikáni Könyvtárat. Eszterházy nemcsak a tudományosságban, hanem a művészetpártolásban, a nagyszabású építkezésekben is a pápa nyomdokait követte, aki odaadó figyelemmel vette gondjaiba az egyetemi oktatást nemcsak Rómában, hanem szülővárosában, Bolognában is. Több új tantárgyat rendszeresített, köztük az anatómiát, eltörölve a boncolásra vonatkozó 13. századi egyházi tilalmat. Nagyvonalúan bővítette az egyetemi könyvtárat, csillagvizsgálót létesített, de jelentős érdemei voltak Róma városrendezése terén is.

20 Diós István: Szentek élete. Bp. 2001. 802-808.

21 Gebei Sándor: Eszterházy Károly egri püspök és a „barokk Eger”. In: Barokk - Történelem irodalom - művészet. Warszawa 2010. 290.

22 Diós I.: Szentek élete i. m. 79-82. 
Ebben az időszakban épült ki a pompás barokk Róma. Ez rendkívüli hatást gyakorolt a fiatal Eszterházyra. A reneszánsz és barokk templomok, a festmények és szobrok, az újonnan feltárt ókeresztény emlékek lenyűgözték a fiatal papnövendéket. ${ }^{23}$

A püspök egyetemalapítási elképzelése meglehetősen illuzórikus volt, hiszen hazánkban a felvilágosult abszolutizmus korában - amikor a legfőbb célkitűzés az oktatás állami kézbe vétele volt - semmi esélye nem volt egy katolikus egyetem alapításának. Még Barkóczy Ferenc esztergomi érsek, a királynő „oktatási tanácsadója” sem támogatta, annak ellenére, hogy egri püspökként kezdeményezője volt az egyetem alapításának. Ennek ellenére nagy szükség lett volna rá, ugyanis a 18. század második felében Magyarországon mindössze egy egyetem működött, az is csonka volt, hiszen két karral létesült, később bővült jogi és orvosi fakultással, miközben Európa többi országában nagyhírű egyetemek sokasága állt az ifúság rendelkezésére. Említést érdemel, hogy hazánkban az egri Líceum volt az első olyan épület, mely kimondottan egyetem céljára épült. Sajnos abban is egyedi, hogy csak több mint 250 év múlva lett belőle egyetem. Az egri Líceum impozáns épülettömege a város egyik szimbólumává vált, és nemcsak Eger, hanem Magyarország egyik legjelentékenyebb építészeti emléke. Eszterházy életművének csúcspontját ez az épület jelenti.

\section{„Legforróbb vágyam, hogy az egri iskola ... universalis Lyceummá fejlődjék"}

Eszterházy 1762. június 29-én vonult be Egerbe, a nap kiválasztása szimbolikus volt: a két fóapostol ünnepén kezdte meg itteni apostolutódi működését. ${ }^{24}$ Október 1-jén tartotta első megbeszélését Josef Ignaz Gerllel, a Barkóczy püspök által megbízott tervezővel. Székfoglalásakor már elfogadott tervek várták, de azután 1765-ben máig ismeretlen okok miatt szakított Gerllel, kifizettetett számára 106 forintot, és soha többé nem kerültek kapcsolatba; Fellner Jakab kapta meg a megbízást. A Gerl által készített terv nem tartalmazta a kápolnát és a színházat, ugyancsak ilyen új, már Fellner beléptével kapcsolatos elem volt a csillagvizsgáló torony is. ${ }^{25}$

Fellner sajátos területe a palotaépítés volt. Ebben a műfajban kiemelkedő alkotásai az egri érseki palota egyes részei, a tatai piarista rendház, a veszprémi agg papok háza, a veszprémi szeminárium, az egri nagypréposti palota, valamint a Batthyány Ignácféle kerti pavilon. Európai mércével mérve is egyik legjelentősebb alkotása a veszprémi

23 Gebei S.: Eszterházy Károly i. m. 290-291.

24 Bitskey I.: „Püspökünk, példánk” i. m. 12.

25 Dercsényi Dezsö - Voit Pál: Heves Megye Mủemlékei II. Bp. 1972. 444. 
püspöki palota (1765-76). Hasonlóan kiemelkedő kvalitású épület a Líceum is. ${ }^{26}$

Fellner honosította meg Egerben az ún. XVI. Lajos (copf) -stílust, amelyet elsőként a Domus Universitatis épületén alkalmazott, majd később a Batthyány Ignác-féle kerti pavilonon és a majdani erdélyi püspök által megrendelt nagypréposti palotán is felfedezhetjük stílusjegyeit. ${ }^{27} 1763$. október 14-én kelt beadványában a püspök így ír terveiről a királynőnek: "Legforróbb vágyam, hogy az egri iskola Felséged védö szárnya alatt universalis Lyceummá fejlödjék. "28

Az egyetemi tervekkel kapcsolatban meg kell emlékezni a püspöknek és Markhot Ferencnek azon kezdeményezéséről, mely szerint megpróbálkoztak Egerben az orvosképzéssel, ami az egyetem negyedik kara lett volna a már meglévő püspöki iskolák (teológiai, jogi és bölcseleti) mellett. Markhot Ferenc a 18. századi magyar orvostörténet egyik legkiemelkedőbb személyisége volt, 1718 táján született, tanulmányait a bolognai egyetemen végezte, ahol a kor legszínvonalasabb képzésében részesült. A balneológiában - vagyis a gyógyvizek segítségével végzett terápiában - különös jártasságra tett szert. Mint Heves és Külső Szolnok vármegyék tiszti főorvosa 1769-ben Eszterházy Károly püspök támogatásával az Irgalmasrendiek egri kórházában kezdte meg az orvosképzést. Ez kiemelkedő jelentőségü kezdeményezés volt, mert az iskolának megvolt a kórházi háttere, ahol a hallgatók a gyakorlatban is megismerkedhettek az orvoslással. Megjegyzendő, hogy ugyanebben az időszakban a nagyszombati egyetem orvosi fakultása semmilyen kórházi háttérrel nem rendelkezett. Mivel Mária Terézia az egri iskolának, a Scola Medicinalisnak nem adta meg a doktoráltatás jogát, 1775-ben jelentkezők hiányában be kellett azt zárni. ${ }^{29}$

A csillagásztorony építésének gondolata úgy született, hogy Eszterházy, amikor még váci püspök volt, megismerkedett az ottani székesegyház általa megbízott mesterének a fiával, Pilgram Antal jezsuita csillagásszal, aki helyettese volt Hell Miksának, a bécsi csillagda vezetőjének. A csillagvizsgáló felállításának tervét erősítette a kor azon szokása, hogy a többi könyvtáralapító püspök is olyan épületekben helyezte el könyvtárát, ahol csillagda is működött. Fellner 1765 májusában jelölte ki a csillagásztorony helyét az épületen belül. 1773 májusára készültek el a meridiánterem boltozatai. Hell a délvonalat carrarai márványból rakatta ki, és felsőtárkányi szürkemárvánnyal szegélyezte azt. Ö írta elő, hogy miként kell kivésni azokat a nyílásokat, melyeken keresztül a napsugár be tud hatolni. Az ő utasitásai alapján emelték a camera obscurát, és alakították ki az obszerváló helyiséget. 1778-ra fejezte be a mozgatható kupola tervét.

26 Lajta Edit [et al.] (szerk.): Művészeti Lexikon II. Bp. 1966. 39-40.

27 Szmrecsányi Miklós: Eger művészetéről. Bp., 1937. 119-120.

28 Szepesy Sándor: Az egri Lyceum bölcsőkora. Egri Egyházmegyei Közlöny. Eger 1893. 164-165.

29 Ringelhann Béla - Soós Imre: Adatok az egri orvosi iskoláról kezdeményezőjének és tanárának, Markhot Ferencnek működéséről. In: Az Országos Orvostörténeti Könyvtár Közleményei. Szerk. Palla Ákos. Bp. 1963. 131. 
A sötétkamra a 9. emeleten kapott helyet, itt szerelték föl azt a periszkópot, amelyet Hell „a vendég mulattatására” tervezett. A torony a mannheimi és a kremsmünsteri csillagvizsgáló tornyokkal mutat formai rokonságot. ${ }^{30}$

A könyvtárral kapcsolatban meg kell említeni, hogy Eszterházyval közel egy időben szinte valamennyi magyar fópap gyüjtötte a könyveket, és hasonló színvonalú könyvtárakat létesített. Ezek egy része az egrihez hasonlóan azzal a szándékkal jött létre, hogy a felsőoktatás céljait szolgálja. ${ }^{31}$ A fôpapi könyvtárak alapításának körülményei között fontos szerepet játszott a római Collegium Germanicum et Hungaricum. Ott végezte tanulmányait a 18 . század szinte valamennyi magyar föpapja. ${ }^{32} \mathrm{~A}$ Collegium Germanicum et Hungaricum diákjai több alkalommal töltötték be a kollégium könyvtárosi állását. Köztük Batthyány Ignác, későbbi erdélyi püspök is, aki például 1766-ban 5.000 kötet könyvvel tért haza Rómából, benne értékes ritkaságokkal, ősnyomtatványokkal és 12-15. századi kéziratokkal. Ott szerzett tapasztalatait - mint egri kanonok - Eszterházy püspök segítőjeként a könyvgyüjtésben nagyon jól kamatoztatta. ${ }^{33}$

Említésre méltó, hogy a 18. század végén alapított püspöki könyvtárak állománya - a gyulafehérvári több mint 18.000 kötetet kivéve - nagyjából 15-16 ezer kötet volt. 1793-ban, mikor az egri könyvtár megnyitotta kapuit a nyilvánosság előtt, a Nagyszombatból Budára költöztetett egyetemi könyvtár állománya is csak 15.000 kötet volt. Tehát a 18. század második felében létesített föpapi könyvtárak - beleértve az egrit is a maga 16.000 kötetével - a könyvek számát tekintve megfeleltek az egyetemi könyvtár kritériumainak (legalábbis Magyarországon). ${ }^{34}$

A könyvtár faburkolatát és állványzatát 1778-ban Fellner Jakab tervezte, és Lotter Tamás egri asztalos 1778-1780 között készítette el. A reliefeket és az egyéb díszítményeket Halblechner Vencel egri szobrász faragta. ${ }^{35}$ A reliefekben megjelenített keresztény tudósok személye jól tükrözi a püspök műveltségének irányait.

A freskó az 1545-től 1563-ig tartott Trienti Zsinatot ábrázolja, összesen 132 alakkal. Johann Lucas Kracker vejének, Joseph Zachnak a segítségével festette 1778ban. A püspök Krackerral mint udvari festőjével nem kötött szerződést, hanem minden egyes munkáját külön díjazta. A könyvtár mennyezetének freskójáért 1600 forintot fizetett. ${ }^{36}$

30 Dercsényi D. - Voit P.: Heves megye i. m. 452-453.

31 Löfler E.: Eger város i. m. 113.

32 Bitskey István: Hungáriából Rómába. A római Collegium Germanicum Hungaricum és a magyarországi barokk művelődés. Bp. 1996. 160-163.

33 Bitskey I.: Római hatások i. m. 83-87.

34 Farkas Gábor Farkas: A nagyszombati egyetemi könyvtár az alapításkor 1635. Fejezetek az Eötvös Loránd Tudományegyetem történetéből 23. Szeged 2001. 32.

35 Szmrecsányi M.: Eger művészetéről i. m. 121.

36 Szmrecsányi M.: Eger művészetéről i. m. 122-123 
A freskó témájának kiválasztása sokat elárul Eszterházy Károly személyiségéről. Az egri Főegyházmegyei Könyvtár egyetemi könyvtárnak készült, és mint ilyenben, legkézenfekvőbb az lett volna, ha a mennyezetkép az egyetemen oktatott négy fakultást ábrázolta volna. De a püspöknek az épület adottságai miatt három, sőt a színházteremmel négy reprezentatív, nagyméretủ terem kialakítására volt lehetősége, ezt a témát pedig a vizsgateremhez tartogatta, ahol azok az események zajlottak, melyek az egyetemi fokozatok (baccalaureatus, magistratus, doctoratus) elnyerése (promóció) alkalmából tartott nyilvános viták voltak.

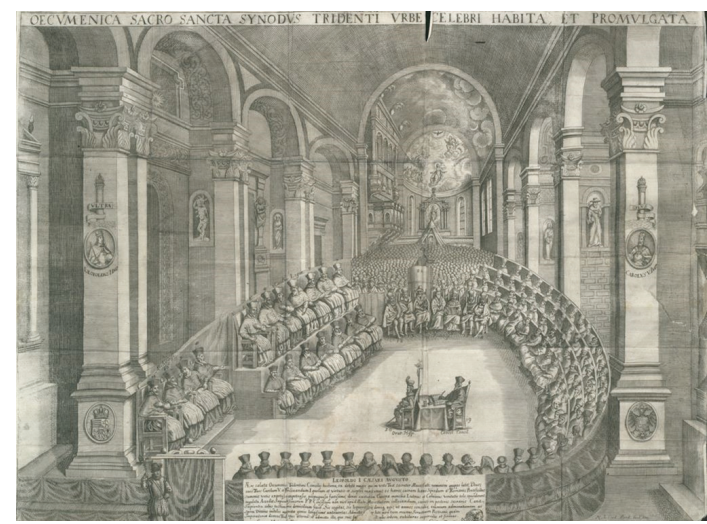

1. kép: Carolus Zanetti metszete: A Tridenti Zsinat, 1673. Forrás: Michelangelo Mariani: Trento con il sacro consilio. Trento 1673.

Egy kánoni látogatás során, a szatmári fóesperesnél látott egy Trienti Zsinatot ábrázoló metszetet, amelyet egy bizonyos Carolus Zanetti készített 1673-ban I. Lipót számára, és ami könyvillusztrációként is megjelent. Ez a téma rendkívül illett a püspök világképéhez, melynek egyik legjellegzetesebb eleme épp a poszttridentizmus volt. A könyv, amelynek a metszet melléklete volt, Michelangelo Mariani Trento con il sacro concilio et altri notabili címü, 1673-ban Trentoban megjelent műve. A metszetet Jávor Anna találta meg a bécsi Universitätsbibliothekban, a könyv magyarországi példányainak viszont egyike sem tartalmazza a szóban forgó mellékletet. Mikor a metszetet átadta Krackernak, arra is utasította, hogy akiknek kiléte a metszeten nincs feltüntetve, azokat egy bécsi jezsuita atya segítségével azonosítsa. Ezen kívül azzal is megbízta, hogy tudakozódjon a jellegzetes ábrázolási módok tekintetében, és nagy gondja legyen a történeti hűségre. ${ }^{37}$ A mennyezetkép a katolikus egyház legfőbb fórumát, a zsinatot rendkívül színpompásan jeleníti meg, és rajta nagyon jól érvényesül a barokk térfokozás a valóságos architektúra látszólagos folytatásával. Ez utóbbi Joseph Zachnak, Kracker vejének a munkája. ${ }^{38}$

A terem négy sarkában négy jelenet látható: a papszentelés, az egyházi cenzúrát szimbolizáló kép, az utolsó kenet kiszolgáltatása, valamint a szentképek és a szent ereklyék tisztelete. Ezek a reformáció által megkérdőjelezett témák egy-egy zsinati dekrétumhoz kapcsolódtak.

37 Kiss Péter: Arcvonások Eger művelődéstörténetéből. Eger 1993. 60.

38 Szmrecsányi M.: Eger művészetéről i. m. 122. 
Mikor a díszteremre került a sor, Kracker már nem volt életben. Ezért a püspök Maulbertschre gondolt, akivel ettől kezdve rendszeres kapcsolatban állt, de ő Győrben volt elfoglalva, így esett a választása Sigristre. Franz Sigrist 1780. december 26-án küldte meg Egerbe az első vázlatokat. Eszterházy a régi bécsi egyetem aulájának freskóihoz hasonlóan képzelte el az egyes tudományszakok ábrázolását, így a művészt megkérte annak tanulmányozására. A szerződésben összesen 3500 forintban állapodtak meg. Sigristnek a fia volt a segédje. Az volt a feladat, hogy a díszterem mennyezetének mind a négy oldalán jelenjen meg egy tudományszak, a jog, az orvostudomány, a bölcselet és a teológia. A vázlatok nincsenek meg, de azt tudjuk, hogy a megrendelő püspök nem volt velük teljesen megelégedve. A freskó 1781-ben készült el, de a művész a következő évben még sok mindent átfestett rajta a püspök instrukcióinak megfelelöen. ${ }^{39}$

A díszterem után 12 esztendővel került sor a harmadik rizalit termére, a kápolnára, melynek mennyezetét Anton Maulbertsch festette 1793-ban. A kép a mennyországot és annak lakóit ábrázolja. A szerződést 1792. szeptember 15-én kötötték, mely a vázlat alapján tartalmazza a leendő kép leírását, amelyet 3300 forint munkadíjért vállalt el a művész. Az oldalfalak és a mennyezet festése között nincs semmi szerves kapcsolat, ez szándékos volt, hogy jobban elváljon egymástól a menny és a föld. A két nagy körben lebegő alakok között a kép centrumában a Szentháromság és Szűz Mária ábrázolása látható. Az Ó- és Újszövetség üdvözültjei kis felhőgomolyokon lebegnek, János evangélistát - az egyházmegye védőszentjét - az egyik kör közepén angyalok viszik az égbe. A másik körben egyházatyák és női vértanúk láthatók. Eszterházy kérésének megfelelően a magyar szentek az oltár feletti részen láthatók. Előttük egy szárnyas angyal az apostoli kettős keresztet emeli a magasba, a másik pedig címeres magyar zászlót lobogtat.

Az oltár falpilléreit és oromzatát, valamint a tabernákulumot Adami János készítette 1793-ban. Az eredeti oltárképet, mely Máriát, Magyarország védőasszonyát ábrázolja az előtte hódoló Szent István királlyal, Huszár Ferenc festette, akit Eszterházy élete utolsó éveiben kezdett el foglalkoztatni, de ezt a képet később Fischer érsek kicseréltette egy ugyanilyen tárgyú képpel, amit Hesz Mihállyal, az egri születésü bécsi festőtanárral készíttetett. Az oltár angyalszobrait és a szószék reliefjeit Motzer József szobrász 1794-ben mintázta. A tabernákulum érdekessége, hogy úgynevezett verde anticóból készült. Ez a Szentpétervár környékéről származó ásvány csak apró darabokban lelhető föl, ezért többnyire ékszereket készítenek belőle. Ez a tabernákulum is több száz kis darabból lett összeállítva. ${ }^{40}$

39 Szmrecsányi M.: Eger művészetéről i. m. 124-126.

40 Szmrecsányi M.: Eger művészetéről i. m. 128-129. 
A három freskó ikonográfiai programja jól tükrözi azt a háromirányú elkötelezettséget, mely a püspök életének vezérmotívuma is volt, a Tridentinum katolikus megújulásban játszott kiemelkedő szerepének, általánosságban az egyház védelmének, a négy fakultás a tudomány iránti elkötelezettségének és az üdvözültek serege, köztük kiemelten a magyar szentek a haza iránti elkötelezettségének akár szimbólumai is lehetnének. Ebbe a programba jól illik a kápolna Szent István király korona felajánlását ábrázoló oltárképe is. De ugyanezt a hazaszeretetet támasztja alá az a tény is, hogy Eszterházy Wittmann János egri festővel egy olyan képsorozatot is készíttetett a Líceum második emeleti folyosójára, amely Szent László legendájából vett jeleneteket ábrázol. ${ }^{41}$

Külön említést érdemelnek az épület mázas cserépkályhái, melyekből Szmrecsányi Miklós szerint 42 darabot, a Heves Megye Műemlékei című topográfia szerint pedig 52 darabot rendelt Eszterházy Mágner Károly győri fazekasmesternél, a legutóbbi kutatások szerint valójában 78 volt a kályhák száma. A kályhák copf stílusban készültek, és részben fehér, részben zöld mázzal lettek bevonva. Díszítményeiket tekintve nincs közöttük két egyforma. 220-280 cm magasak, valamennyi kályha 30-40 cm-es lábakon, vasból vagy rézből készült tálcákon áll. Ma már a kályhák közül mindössze $17 \mathrm{db}$ található eredeti helyén, a többit elbontották, a Dobó István Vármúzeum raktárában körülbelül ugyanennyinek a maradványai léteznek még, a többi elkallódott. ${ }^{42}$

$\mathrm{Az}$ érseki, korábban püspöki palota középső szárnyát Erdődy püspök építtette, melyre utóda, Barkóczy még egy emeletet húzatott. Eszterházy Károly jelentős változtatásokat hajtott végre az épületen. A püspök Fellner Jakab tervei alapján azzal a két szárnnyal bővíttette, melyek magukban foglalják a kocsiáthajtót, valamint a kápolnát, melyet a püspök 1766. szeptember 7-én szentelt föl a Szent Kereszt tiszteletére. A palotának ez a legértékesebb része, amely két emelet magasságát foglalja el, oltárának két oldalán felsőtárkányi márványból készült lapos pillérek, lángoló urnákkal díszített párkányzattal. Ezek adják meg az oltárt díszítő szoborkompozíció keretét, mert kép helyett a sárgás stukkó alapba egy egyszerű, felsőtárkányi fekete márványból készült kereszt van illesztve, a Megváltó ólomból öntött alakjával. A kápolna falait mümárvány borítja, melyeket aranyozott rokokó ékítmények díszítenek. A bővítést és az átalakítást Fellner Jakabbal terveztette meg Eszterházy püspök. Az épületet mind északi, mind déli irányba meghosszabbította, mindkét végébe jól elkülönítheto”, balluszteres korlátokkal díszített végszárnyat, ún. „galériát” építtetett, melyek tetejét szobrok díszítették.

A déli oldalon lévő szárnyba helyezte az új kápolnát, melynek mennyezeti freskóját Johann Lucas Kracker készítette, mely Krisztus feltámadását ábrázolta. A freskó

41 Dercsényi D. - Voit P.: Heves megye i. m. 473.

42 Kiss Adrien: Az egri Líceum és kályhái. Eger 2013. 41. 


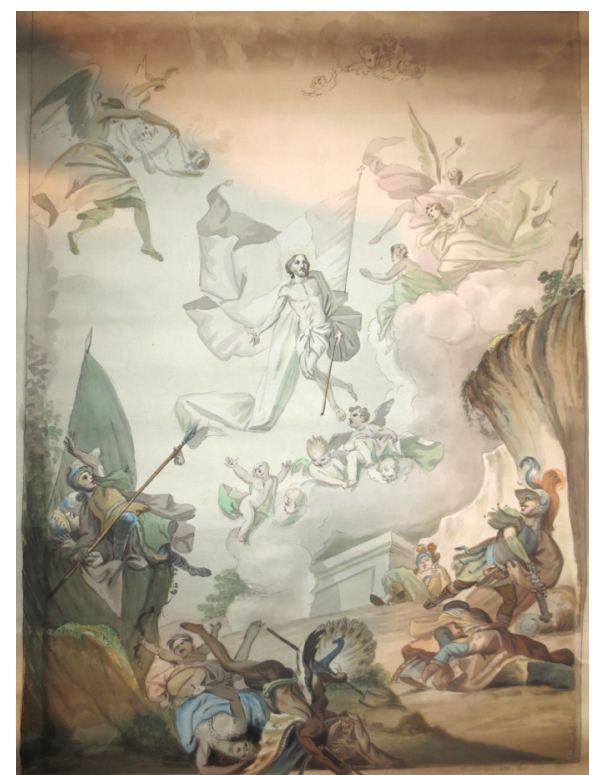

2. kép: Franz Hauptmann: Johann Lucas Kracker Krisztus feltámadása cimü mennyezetfreskója a Püspöki (ma Érseki) Palota magánkápolnájának leégése után, 1816-ból. Akvarell, papir, $630 \times 465 \mathrm{~mm}$.

(Köves-Kárai Petra felvétele) az 1801-es tủzvész során semmisült meg, ma egy id. Storno Ferenc által készített freskó díszíti a kápolnát, 1877-ben pótolták a megsemmisült freskót. A kép a gyermek Keresztelö Szt. János és a kis Jézus találkozását ábrázolja. Az oltárt díszítő ólomfeszület Georg Leitner bécsi szobrász munkája, az oltárasztal szürke márványból készült koporsó alakú építmény. A tabernákulum Schäjrer József egri ötvös munkája 1765-ből. Az építkezés során keletkezett iratok tanúsítják, hogy valahol itt lehetett az üvegház, az orangéria, amit a kápolna építése miatt kellett elbontani. ${ }^{43}$

Az épület északi végében a korábbi külső lépcső helyett egy reprezentatív belső lépcsőházat alakíttatott ki, amely a kápolnán kívül az épület legimpozánsabb része, és melynek földszintjén egy kocsiáthajtó kapott helyet, melyet keleti oldalán egy díszes, nyugati oldalán pedig egy szerényebb kapuval láttak el. Ezáltal a keleti, díszudvar felőli kapu vált a palota föbejáratává. Hintóval be lehetett állni az előcsarnokba, és miután az utasok kiszálltak, a hintó továbbhajtott, ki a hátsó kapun, és egy éles kanyarral közelítette meg az istállóudvart, illetve a kocsiszíneket. ${ }^{44}$

A fóépület, amely Barkóczy püspök jóvoltából korábban már egy emelettel is bővült, most már teljesen összeépült az északi szárnnyal, amelyben immáron a személyzet került elhelyezésre, az északi szárny legnagyobb földszinti terme volt a személyzeti ebédlő, a sarokban lévő helyiségekben pedig a konyha müködött ${ }^{45} . \mathrm{Ez}$ utóbbi maradványai az utóbbi időben feltárásra is kerültek.

Eszterházy Károly püspök különös gondot fordított az egri szeminárium fejlesztésére is, Az épület 1772-ben Fellner Jakab tervei alapján emeletráépítéssel bővült. ${ }^{46}$

43 Szmrecsányi M.: Eger művészetéről i. m. 110-112.

44 Dercsényi D. - Voit P.: Heves megye i. m. 498.

45 Dercsényi D. - Voit P.: Heves megye i. m. 493.

46 Sugár I.: Az egri püspökök i. m. 435. 
A Historia Domusban erről a következők szerepelnek: „A szeminárium tetejét a negyedik contignatio (3. emelet) ráépitése céljából egy emelöszerkezettel megemelték, de mivel nem tudták egyensúlyban tartani, leszakadt. Ezért a püspök elrendelte az emelögép szétbontását, majd felépitették a falakat és ráépitették a tetöt. Ezt követöen Grossmann József és Francz József is készitett terveket a Szeminárium bövitésére, amelyek közül a Grossmannéi valósultak meg, 1784-ben kezdték el a Foglár utcai épületszárny kivitelezését. "Ebben az új kelet-nyugati irányú épületrészben kapott helyet a kápolna, a refektórium és a lépcsőház. Amikor 1784-85-ben ismertté vált, hogy II. József a megszüntetett egyházmegyei papneveldék helyett az egyik kerületi szemináriumot Egerbe akarja telepíteni, Eszterházy lázas sietséggel egy új szárnyat emeltetett hozzá. Miután II. József halála után visszavonta az egyházzal kapcsolatos rendeleteit, és visszaállt a régi rend, az ily módon túlságosan naggyá vált épületben a püspök arra kívánt lehetőséget biztosítani, hogy más egyházmegyék növendék papságát is itt képezzék. Ennek érdekében tovább folytatta a bővítést. ${ }^{47}$

A szeminárium épületével kapcsolatban említést érdemel még az elaggott papok elhelyezésére szolgáló épület, a Domus Emetitorum Parochorum, a mai Szent József Kollégium épülete a szeminárium szomszédságában. Az épületet Kiss János kanonok adományozta a fenti célra, ám a bejárat fölött olvasható kronosztichon szerint csak 1769-ben kezdte el betölteni az alapító szándéka szerinti funkcióját, addig az idős papokat a szemináriumban látták el, ebben az épületben pedig konviktus működött. Eszterházy püspök 1768-ban döntött úgy, hogy az épület nyerje vissza eredeti funkcióját. Oltárképét Szmrecsányi Miklós szerint Johann Lucas Kracker készítette, Szent József halálát ábrázolja. ${ }^{48}$

1769-71 között került sor a kertek kialakítására. A díszkert a Bél Mátyás leírásából ismert Erdődy-féle vadaskertek egyikéből létesült, mégpedig Barkóczy idejében. Trapéz alaprajzú, két széles, egymást derékszögben metsző út képezi a park vázát a találkozásuknál rondóban kialakított francia kerttel. A négysoros vadgesztenyén és a középső körön meglátszik a francia kertépítészet hatása. A terv valószínűleg a püspök geometrájának, Házael Hugó szervita barátnak a munkája, aki nemcsak számos szép kivitelü birtoktérképet készített a püspök számára, hanem amikor Barkóczy esztergomi érsek lett, több gyönyörű kerttervet készíttetett vele. Eszterházy 1769ben kezdte el a park bekeríttetését, mely korábban csak palánkkal volt körülvéve, és amelybe ettől kezdve remek vasrácsos kapukon át lehetett bejutni. Ekkor épült a legdíszesebb, északi kapu. Ma már pontosan megállapíthatatlan, hogy a kertnek hány kapuja volt, azt azonban bizonyosan tudjuk, hogy a meglévőkön kívül

47 Dercsényi D. - Voit P.: Heves megye i. m. 289.

48 Kiss Péter: Adatok az egri Domus Emeritorum Parochorum történetéhez. In: Eszterházy Károly emlékkönyv, Szerk. Kovács Béla. Eger 1999. 249-250. 
1966-68 között minden évben lebontottak egyet-egyet. A kerítés köveit a Rác kapunál lévő városfalszakasz lebontásából nyerték. Fazola Lénárd ekkor 3317 font rúdvasat kapott a nagykapu elkészítéséhez. A falakat Povolni János építette, a kőkockákat pedig részben Miller János, részben Adami József faragták ki. A kert hátulsó végén, az Eger patakon és a malomárkon át bájos kőhíd vezetett keresztül egy nyári kastélyhoz, melyet Eszterházy 1770-71-ben újjáépített, és Krackerral 1772-ben kifestetett. A romokból megmaradtak faragott kövek, oválisan áttört, rózsakelyhekkel díszített balluszterek, gyümölcsös vázák, virágos oszlopfők, melyekből Pyrker érsek utolsó titkára, Majzinger Károly a kerecsendi plébánia kertjében egész gyüjteményt helyezett el, mikor ott lett plébános. A tervezést feltehetőleg Fellner végezte, és Hesz János, valamint Steinhauser Antal szobrászok faragták ki a szép formákat. Ezzel egyidejűleg történt az érseki palota kerítésének megépítése is. ${ }^{49}$

Eszterházy Károly a fürdöt is jelentősen átépíttette, elsősorban azért, mert fontos bevételi forrásnak tekintette. A fürdő (az egykori Arnaut pasa fürdője) egy úgynevezett ilidzsa volt, melyet még a törökök építettek a 91 évig tartó hódoltság alatt. Az alapfalak ásásához 1795 januárjában láttak hozzá, nagyon nehezítette a munkát a források minduntalan feltörő vize. Ekkor boltozták be a nyolcszögletű török medencét, és a már korábban is meglévő egyik Extra-Bad mellé egy másikat is építettek. Az építkezésen a legjobb hírủ mesterek dolgoztak: Franz József építészen kívül Pliczner János kőfaragó, Ploreczky György ács- és Fazola Lénárd lakatosmesterek. A költségek 2600 forintra rúgtak. ${ }^{50}$

1771 és 1781 között építtette meg a püspök azt a völgyzáró gátat, mely Eger várost volt hivatott a patak árvizeitől megvédeni. A városon keresztülfolyó patakocska ugyanis a heves nyári záporok idején gyakran kilépett a medréből, hatalmas károkat okozva a településen. Az uralkodó szélirány miatt a felhőszakadások ugyanis Egertől északra, a Bükkben kezdődtek, és néhány óra múlva, mire a zivatarfelhők a város fölé érkeztek, a patak medre már tele volt a hegyekben leesett eső vizével. A terveket Zathureczky Sándor városi geometra készítette, a kivitelezés pedig Povolni János nevéhez füződik. Az építmény egy 240 m hosszú és 3,78 m széles híd volt, mely keresztbe szelte a patakot, és pillérei között két nyílás volt, melyeken csak annyi víz juthatott az Eger-patak medrébe, amennyit az biztonsággal le tudott vezetni. A híd a Mária utca vonalában helyezkedett el, és utolsó nyomai csak néhány évtizeddel ezelőtt tűntek el teljesen. A tervek alapján az óriási gátfalon a zsilip fölött egy nyitott kápolna volt. A kápolna közepén Szűz Mária szobra állt, egyik oldalán Szent Mihály, a város védőszentje, másik oldalán pedig Nepomuki Szent János szobraival. A kápolna tornyában harang is volt, amely vészjelzőként szolgált. A védművet a püspök

49 Dercsényi D. - Voit P: Heves megye i. m. 321-332.

50 Dercsényi D. - Voit P.: Heves megye i. m. 301. 
1781. május 22-én áldotta meg az Énekek énekéből vett idézettel: „Posuerunt me custodem in vineis, vineam meam non custodivi" (Én. 1. 5.) (Szölöt öriztettek velem, a magam szölöjét azonban nem öriztem), mely szavakat a híd falára is felvésték. Így a védmű hivatalos elnevezése is Posuerunt lett. ${ }^{51}$ Ezzel összefüggésben a püspök 1780-ban a patak szabályozására is megbízást adott Fellner Jakabnak, de annak halála után Grossmann József kapta meg a feladatot. ${ }^{52}$

A régi székesegyházat a püspök igyekezett szépíteni, csinosítani addig is, amíg - tervei szerint - hozzá nem tud fogni az új katedrális építéséhez. Elsőnek a szentélyt díszíttette ki, 1765-ben tárkányi márványból új föoltárt építtetett Rupert Schnattmann bécsi márványfaragó mesterrel 3000 forintos költségen, s föléje Krackerral megfestette az új oltárképet is, mely olajbafőtt Szent Jánost ábrázolta, és amely most a sátai templomot díszíti. A szentély és a Mária-kápolna mennyezetfreskóját 1767-ben Kracker festette meg 2700 forintos tiszteletdíjért. ${ }^{53} 1769$-ben Eszterházy Schnattmannal készíttetett még két márványoltárt, melyek fölé Szent István és Szent László oltárképeit ugyancsak Kracker festette meg 1773-ban. ${ }^{54}$ A két kép ma a székesegyház oldalhajóinak utolsó két mellékoltárát díszíti.

Szmrecsányi Miklósnál, Eger művészeti értékeinek eddigi legjobb ismerőjénél olvashatjuk az alábbi gondolatokat, melyeket tulajdonképpen maga is idéz: „Eszterházy Károly, Egernek utolsó püspöke átellenben a püspöki kisded és dísztelen templommal alkotá a Lyceumot királyos költséggel, s úgy szándékozván, hogy ha majd ezt elvégzendi, elhordattya a disztelen templomot, sollyat állit, melly a Lyceum mellett méltólag foglal helyet." (Kazinczy Ferenc) ${ }^{55}$

Nováky József kömlői plébános gyászbeszédében így emlékszik meg erről: „,.. kivánva kivánta Eger városát egy roppant templommal felékesiteni, annak leendö formáját többször kirajzoltatta, annak helyét kitzövekeltette, mindazonáltal sok izben megújitott feltételét nem teljesithette. ${ }^{56}$

Eszterházy Károly elsőként Grossmann Józseffel készíttette el a székesegyház terveit. Úgy tűnik azonban, hogy Grossmann terveivel nem volt megelégedve, mert két év múlva új megrendelést adott Karl Zillachnak, aki a magyar királyi kamara és a prímás építésze volt. A két terv nagyjából azonos méreteket és elrendezést tartalmazott, azok színvonala között azonban nagy különbség van Grossmann javára. A tervek készítésének mindkét esetben maga a püspök volt az irányítója, és ez

51 B. Pap Györgyi: Árvíz Egerben 1878. augusztus 30-31-én. In.: Agria Annales Musei Agriensis XXXIV. Szerk. Petercsák Tivadar. Eger 1998. 5.

52 Breznay Imre: Eger múltjából. Eger 1926. 44.

53 Sugár István: Az egri bazilika. Bp. 1971. 17-18.

54 Egri Főegyházmegyei Levéltár Archivum Vetus (EFL AV) 2777. Kracker levelei Eszterházyhoz.

55 Szmrecsányi M.: Eger művészetéről i. m. 144-147.

56 Nováky J.: Halotti dicséret i. m. 9. 
nemcsak a rendeltetés eszméjére, a szükséges méretekre vonatkozott, hanem a formai megoldásokban, a művészi alakításokban is az ő elgondolásai érvényesültek. Mindkét alkalommal a térrendezés egységessége lebegett a megrendelő püspök szeme előtt. Mindkettő úgy készült, hogy a tervezett katedrális a Líceum tengelyébe épült volna (a barokk székesegyház homlokzata a Hatvani kapu irányába nézett), tehát Eszterházy terveiben is a később megvalósított térrendezés volt az egyik legfontosabb szempont, amely szerint az egymással szemben álló két épület a városkép szempontjából azonos súllyal esik latba, sőt együttesen váltják ki azt a lenyügöző hatást, amelynek ma a szemtanúi lehetünk. ${ }^{57}$

\section{A megvalósult „kis Róma”}

Összefoglalva a püspök egri tevékenységét megállapítható, hogy Eszterházy Károly valóban koncepciózusan folytatta székvárosának fejlesztését, építkezéseinek célja egy intézményrendszer megvalósítása volt. Mindössze a szeminárium bővítésével kapcsolatban tapasztalható némi átgondolatlanság, ami azután további kapkodásba torkollott. A püspök illúziókba ringatta magát azzal összefüggésben, hogy az uralkodó II. József ígéretét bírta arra vonatkozólag, hogy a szemináriumok államosítása és összevonása után az egyik kerületi szeminárium Egerben fog működni. A papnevelde ily módon végrehajtott bővítései teljesen indokolatlanok voltak, különösen annak ismeretében, hogy a papképzés oktatási része a Líceumban zajlott, a szeminárium mint konviktus a növendékek szállása és a papnevelés színhelye volt.

A püspök által létesített épületek elsősorban a kultúrát és a hitéletet szolgálták, de találhatunk köztük olyat is, amelynek funkciója a szociális gondoskodás, a lakosság jobb ellátása vagy éppen a város védelme volt a rendszeresen fenyegető árvizekkel szemben. Úgy véljük, hogy még az egyetlen „csupán” reprezentációs funkcióval rendelkező épület, a püspöki palota sem a saját kényelmét szolgálta, hanem személyétől függetlenül a hivatalának és az egyháznak kijáró tisztelet vezérelte a püspöki palota bővítése során. Szimbolikus jelentősége volt annak is, hogy a felsőtárkányi és a harsányi kastélyokat - püspöki nyaralókat - egyaránt lebontatta, úgy vélte, hogy az azokban megtestesülő luxus, valamint a bennük korábban lezajlott mulatságok nem méltóak fôpásztori hivatásához.

Építkezései során a kor legjelesebb építészei, festői és szobrászai kaptak tőle megbízást. Eszterházy nem egyszerűen megrendelő volt, hanem igényes műértő, aki

57 Szmrecsányi M.: Eger művészetéről i. m. 144-147. 
birtokában volt mindazon képességeknek, melyek segítségével a művészi produktumokat értékelni és minősíteni tudta. Ebben az értelemben mecénási tevékenysége korrekt szerződéseken alapult, melyek minden egyes pontját következetesen betartatta és betartotta. Az általa alkalmazott művészeket maga instruálta, egy-egy templom vagy épületbelső ikonográfiai programját személyesen dolgozta ki. Erre a legjobb példa a líceumi freskók témájának kiválasztása, különösképpen a könyvtáré, mely sűrítve magába foglalja a püspök egész világképét, melyben hit és tudomány szerves egységet alkottak. A hitnek ugyanis nem a tudomány, hanem a hitetlenség, a tudománynak pedig nem a hit, hanem a tudatlanság az ellentéte. Több általa megvalósított épület - a szeminárium emeletráépítése, a Posuerunt vagy a Líceum csillagvizsgáló tornya - arról tanúskodik, hogy műszaki, természettudományos ismereteknek sem volt híján. Rendkívüli műveltségének legékesebb bizonyítéka a 16 ezer kötetes egyetemi könyvtár létrehozása, mely a tervezett négy fakultás igényeinek megfelelően a kor legmodernebb szakirodalmával várta olvasóit.

A 18. század négy nagy építő püspöke - Telekesy István, Erdődy Gábor, Barkóczy Ferenc és Eszterházy Károly - közül ő volt az egyetlen, aki olyan nagyszabású tervekkel érkezett egyházmegyéje élére, melyek koncepciót sejtetnek nemcsak székvárosának igazi püspöki székhellyé való alakításában, hanem az egyházmegye, illetve annak központja működésének tekintetében is. A püspöksége alatt városunkra ragasztott jelzők: „kis magyar Róma” vagy „magyar Athén” jelzik tevékenységének irányait, miszerint az egyházmegye szakrális centrumát külsőségeiben és szellemileg is hozzá akarta igazítani a funkcióhoz. A Rómában tanult fôpapok - köztük Eszterházy onnan hozták tudásukat, invencióikat, Rómából kaptak eligazítást egyházszervezői tevékenységükhöz, sőt többnyire itáliai művészeket, építészeket is foglalkoztattak, akik azután itt műhelyt teremtettek, tanítványokra találtak. Athén nevének szimbolikus használatát a püspöki iskolák megszervezése, illetve működése indokolta, amit az egyetem alapítása koronázott volna meg, de a Domus Universitatis létrejötte mindenképpen hangsúlyossá tette azt a tényt, hogy Eger az egyetem nélkül is a tudományok fellegvára volt. ${ }^{58}$

$\mathrm{Az}$ új szerephez idomult a város szerkezete is. A török hódoltság előtt még a vár volt a település és a püspökség központja. A 18. század elején Telekesy István kezdte kiépíteni az új püspöki lakhelyet a forgalmas, a Felvidékre vezető fóútvonal mentén, az egykori Hosszú utcában, az elpusztult várbeli épületek pótlására. Ezt követően pedig az Erdődy Gábor által épített kelet-nyugati tájolású palotaszárny volt a város legreprezentatívabb épülete, amely egyben Eger új centrumát is jelentette. Erdődy utóda, Barkóczy Ferenc is sokat hozzátett a püspöki székhely

58 Bitskey István: Eger a barokk kori Közép-Európában. In: Az egri Domus Universitatis és Líceum. Oktatás, tudomány, művészet 1773-2013. Szerk. Petercsák Tivadar. Eger 2013. 38-39. 
és környéke csinosításához (Megyeháza, felsőtárkányi Fuorcontrasti kastély és a barátréti nazarénus kolostor). Entz Géza művészettörténész szavaival élve: „... Barkóczy püspöksége alatt a legjelentösebb érett barokk épületek (minorita templom, trinitárius templom, megyeháza) rangot és szinvonalat jelentenek az egész város számára, s bizonyos mértékig alapot is adnak a továbbfejlödésre. ${ }^{59} \mathrm{Ez}$ a továbbfejlődés az évszázadból még hátralévő négy évtizedben, Eszterházy idejében teljesedett ki.

Eszterházy Károly alatt azonban paradigmaváltás is bekövetkezett; egyrészt csúcspontjára érkezett az a folyamat, amelyet elődei elkezdtek, másrészt áttevődtek a hangsúlyok, nemcsak külsőségekben, hanem szellemi-spirituális értelemben is. Továbbra is fontosak maradtak a reprezentatív épületek, a műalkotások, de felértékelődött a tudás, a műveltség és a kultúra, amely immáron intézményes keretek közt gyarapodhatott, és egyre több ember számára elérhetővé vált.

Azt sem szabad figyelmen kívül hagyni, hogy a püspök mellett és részben az ő hatására a szerzetesrendek és a káptalan tagjai is számottevő építkezésekbe kezdtek, és ők is alkalmazták a püspök által idehívott művészeket. Ebben az időszakban fejeződött be a minoriták templomának építése (Kilian Ignaz Dientzenhofer tervei alapján), melynek pompás oltárképét (Páduai Szent Antal a Szűz Mária előtt) Kracker festette. Az egykori jezsuiták, ma ciszterciek templomában is látható egy Kracker-mellékoltárkép Szent Anna, Joachim és a gyermek Mária alakjával, a fölötte lévő freskó ugyancsak Kracker műve, egy angyal tartja magasba a 12 csillagból álló koronát. Sajnos, a Kracker által készített mennyezeti freskók az 1800. augusztus 23-i tűzvészben elpusztultak. ${ }^{60}$ Szintén Kracker festette az Androvics Miklós által épített kispréposti palota dísztermének mennyezeti freskóját (Az erény diadala a bűn fölött). Fellner Jakab tervezte a bájos Batthyány-féle kerti pavilont és a szintén Batthyány, illetve Dobronyai Miklós által építtetett nagypréposti palotát.

Ezek a jelentős építkezések inspirálták a tehetős polgárságot is, hiszen ebben az időben nőttek ki a földből azok a belvárosi barokk lakóházak, melyek ma is meghatározói a városképnek.

Mi sem bizonyítja jobban, hogy a püspök tényleg csúcspontra juttatta székvárosát, mint hogy halálát követően megtorpant a négy évtizeden át tartó töretlen lendület, és bár igaz, hogy Pyrker és Bartakovics érsekek személyében a 19. században is kerültek valóban nagyformátumú főpapok az egyházmegye élére, egyiküknek sem sikerült túlszárnyalni Eszterházy püspök teljesítményét.

59 Entz Géza: Opponensi vélemény Voit Pál „Eger művészetföldrajza és a közép-európai barokk” c. kandidátusi értekezésről. In: Művészettörténeti Értesítő I-II. Bp. 1968. 148-150.

60 Breznay I.: Eger múltjából i. m. 80. 


\section{Bischof Károly Eszterházy und seine Residenzstadt Eger}

Der herausragendste Bischof in der Geschichte der Diözese Eger war Károly Eszterházy, der zwischen 1762 und 1799 das Amt des Bischofs innehatte.

Er kam in einer der reichsten aristokratischen Familien Ungarns auf die Welt, und bereitete sich schon seit jungen Jahren auf eine geistige Laufbahn vor. Sein Studium absolvierte Eszterházy an der Heiligen Gregorius Universität in Rom, wo er nicht nur eine außergewöhnliche Bildung erhielt, sondern auch die Gelegenheit bekam, Papst Benedikt XIV., der zu seinem Vorbild wurde, kennenzulernen. Er machte dort ebenfalls die Bekanntschaft zahlreicher Wissenschaftler und Künstler, die im Dienst des päpstlichen Staates standen.

Nach seiner Rückkehr nach Ungarn übte Eszterházy auf seinen eigenen Besitztümern jenseits der Donau die Priestertätigkeit aus. Während dieser Zeit gab er die Errichtung zahlreicher Bauwerke in Auftrag, von denen die wichtigsten die große Kirche in Pápa (Poppa) und das dortige Schloss sind.

Bereits mit 34 Jahren wurde er zum Bischof von Vác (Waitzen) ernannt, wo er gleich mit dem Bau der Kathedrale begann. Nach seinen Plänen hätten die Kathedrale und das damit verbundene Priesterseminar und der Bischofspalast eine Einheit gebildet. Nachdem er aber 2 Jahre später zum Bischof von Eger ernannt worden war, wartete die Realisierung seiner Pläne auf seinen Nachfolger.

Während der 37 Jahre in leitender Position des Bistums Eger wurde er zu einem hochkarätigen Bischof. Er bereicherte die Stadt mit bedeutenden Gebäuden, die bis heute das Bild der barocken Innenstadt prägen. Sein größtes Werk war die Realisierung des Universitätsgebäudes, das das größte Bauwerk Ungarns im Stil von Ludwig XVI. ist. Das Universitätsgebäude verfügt über eine prächtige Bibliothek, einen Prüfungssaal und eine Kapelle, die alle mit Fresken von berühmten Malern verziert sind. Besonders erwähnenswert ist der Turm der Sternwarte, der heute ein Museum der Astronomie beherbergt.

Der Bischof ließ den Bischofspalast und das Gebäude des Priesterseminars renovieren und erweitern einen französischen Park auf dem Gelände des ehemaligen Wildparks errichten sowie das bereits im 17. Jahrhundert von den Türken erbaute Bad modernisieren.

Eszterházy kümmerte sich ebenfalls um den Hochwasserschutz von Eger. Er veranlasste den Bau eines Dammes am Nordrand der Stadt. Dieser ließ nur so viel Wasser durchfließen, wieviel das Bachbett ohne Gefahr aufnehmen konnte. Für die Bauarbeiten beschäftigte er namhafte Künstler (Architekten, Bildhauer und Malermeister), die ihr bedeutendes Lebenswerk- in erster Linie in Eger- hinterließen. 
Von den vorgenommenen Aufgaben konnte Eszterházy lediglich den Bau der neuen Kathedrale nicht realisieren, obwohl die Pläne ihn von Anfang an beschäftigten. Die Realisierung schob er auf sein Lebensende hin, weswegen die Kirche bis zum Zeitpunkt seines Todes 1799 nicht fertiggestellt wurde.

Die Bauvorhaben des Bischofs waren nicht eigennützig. Wichtige Institutionen wie Hochschulen, Druckerei, Bibliothek wurden in den neugebauten oder renovierten Gebäuden betrieben. Damit vollzog sich ein Paradigmenwechsel. Mit diesen Bauwerken wurde nicht nur das Außenbild der Stadt verändert, sondern seine Residenzstadt Eger wurde zur Hochburg der Wissenschaft und der Kunst.

\section{Biskup Karol Eszterházy a jeho sídlo, Jáger}

Karol Eszterházy bol v 18. storočí najvýznamnejším biskupom jágerskej diecézy. $\mathrm{Na}$ biskupskom stolci sedel medzi rokmi 1762-1799. Narodil sa v roku $1725 \mathrm{v}$ jednej z najvýznamnejších rodín dobového Uhorska a od mladého veku sa pripravoval na cirkevnú dráhu. Vysokoškolské štúdia skončil na Univerzite sv. Gregora v Ríme, kde získal nielen mimoriadne vzdelanie, no mal možnost́ sa osobne poznat s pápežom Benediktom XIV. (stal sa jeho vzorom) ako aj celým radom vedcov, umelcov stojacich $\mathrm{v}$ pápežských službách. Po svojom návrate pôsobil ako farár na svojich zadunajských majetkoch, zároveň započal mnohé stavebné aktivity. Z nich najvýznamnejšou je kostol v Pápe a prestavba tamojšieho kaštiela.

Ako mladý, len tridsatštyri ročný sa stal biskupom vo Vacove, kde začal s budovaním tamojšej katedrály. Podla jeho predstáv, tá mala byt spolu s kňazským seminárom a biskupským palácom súčastou väčšieho stavebného komplexu. Nakol'ko sa však už o dva roky stal jágerským biskupom, realizácia tejto úlohy čakala na jeho nasledovníka.

Počas 37 rokov na čele jágerskej diecézy sa stal skutočne vel'koformátovým biskupom. Sídelné mesto Jáger obohatil viacerými významnými stavbami. Tie sú dodnes markantnými barokovými činitel’mi centra mesta. Jeho najväčším dielom bolo vybudovanie univerzitného komplexu - najväčšej uhorskej stavby v štýle Ludovíta XVI. Jej súčastou je knižnica, kaplnka, skúšková sála - všetky sú zdobené freskami slávnych majstrov. Osobitne treba spomenút tunajšiu hvezdáreň, ktorej veža dnes plní funkciu hvezdárskeho múzea.

Biskup nechal obnovit a zväčšit biskupský palác, budovu seminára, na mieste niekdajšieho zverinca zriadil francúzsky park a zmodernizoval kúpele, postavené Osmanmi ešte v 17. storočí. Vel'kú pozornost venoval aj protipovodňovým prácam. 
V snahe uchránit mesto od záplav potoka Eger nechal na severnom konci mesta vybudovat mohutnú hrádzu, ktorá púštala do potoka regulované množstvo vody.

$\mathrm{Na}$ stavebných prácach zamestnával kvalitných umelcov (stavbárov, sochárov, umeleckých maliarov atd.), ktorí zanechali za sebou významné životné diela - z vel'kej časti aj v Jágri.

Z vytýčených ciel'ov sa mu nepodarilo zrealizovat iba jeden: výstavbu novej sídelnej katedrály, a to i napriek tomu, že ho plány súvisiace s kostolom zamestnávali už od začiatku. Realizáciu však nechal na záver, a tak kostol nebol do jeho smrti v roku 1799 dostavaný.

Stavebné aktivity biskupa neboli samoúčelné. Vo vynovených alebo novopostavených budovách fungovali dôležité inštitúcie (školy vyššieho typu, tlačiareň, knižnica), čím došlo $k$ dôležitej zmene paradigiem. Stavebnými aktivitami nielenže zmenil vonkajší obraz mesta, ale preformoval ho na akropolu vedy a kultúry. 